\title{
Chemical characterization methods for biodegradable organic wastes with relevance for the composting process. Case study
}

\section{GINA ALINA CATRINA ${ }^{1 *}$, LIDIA KIM ${ }^{1}$, AGNES SERBANESCU ${ }^{1}$, GEORGIANA CERNICA ${ }^{1}$, COSTEL BUMBAC ${ }^{1}$, MARIUS SBURLIS ${ }^{2}$}

${ }^{1}$ National Research and Development Institute for Industrial Ecology - ECOIND, 71-73 Drumul Podul Dambovitei Street, 060652, Bucharest, Romania

${ }^{2}$ SC Salubris SA, 2A Aleea Tineretului Street, 230081, Slatina, Olt County, salubris_slatina@yahoo.com, Romania

*Corresponding author: gina.catrina@incdecoind.ro

$\begin{array}{lll}\text { Received: } & \text { Accepted: } & \text { Published: } \\ \text { 02.11.2021 } & 15.12 .2021 & 17.12 .2021\end{array}$

\begin{abstract}
The study aimed to develop some methods for the compositional characterization of biodegradable waste with relevance to the composting process at the laboratory level. For testing, four waste fractions were selected, such as waste based on dehydrated sludge, waste from parks (leaves, branches), market waste (mixture of vegetable and fruit) and cardboard waste. For metals and phosphorus, several microwave digestion methods were applied. The ammonium nitrogen content $\left(\mathrm{NH}_{4}-\mathrm{N}\right)$ was determined using a number of extraction procedures (water, $\mathrm{CaCl}$, and $\mathrm{KCl}$ ). Three certified reference materials were used for testing the validity of the results. Recovery percentages higher than $90 \%$ were obtained. The developed and validated methods are suitable for biodegradable waste characterization used in composting processes.
\end{abstract}

Keywords: biodegradable waste, composting, metals, ICP-MS

\section{INTRODUCTION}

Bio-waste is defined as a complex mixture of different proportions: biodegradable garden and park waste, household food and kitchen waste, restaurants, catering and retail space and similar waste from food processing plants [1].

The main environmental problem induced by biodegradable waste is methane emission into the air during the decomposition of waste deposited in municipal landfills. In the EU, from total greenhouse gas emissions accounted for in 2019, approx. 9\% are associated with biodegradable waste. Directive EU 2018/851 states that the Member States must ensure by the end of 2023 that bio-waste is either separated and recycled at the source or collected separately and not mixed with other types of waste. Also, according to the same Directive, the Commission calls on European standardization organizations to develop European standards for the bio-waste subject to organic recycling, compost, and fermented product, based on best available practices [2]. The amount of waste that undergoes aerobic or anaerobic treatment may be considered as recycled, provided that such treatment generates materials to be used as recycled products, materials, or substances [2].

From 1 January 2021, local public administration authorities or the administrative-territorial subdivisions of municipalities and their inter-community development associations, respectively, must implement the system of separate collection of biodegradable waste. This action was imposed in order to reduce the separate door-to-door collection of bio-waste in urban areas, doubled by the implementation of the "pay for how much you throw away" scheme and encouraging individual composting in rural households [3]. 
A first step in recycling biodegradable waste by composting is the characterization of waste suitable for composting. Therefore, appropriate methods for the analysis of critical compounds in biodegradable waste must be identified [3-5].

In the fermentation process, trace elements, such as copper and zinc, and soluble forms of magnesium, potassium, and calcium are essential for microbial growth. [5-6]. Metal ions are essential for microbial growth, and similarly, with other nutrients such as nitrogen and phosphorus, they influence the specific growth rates of bacteria [5-12].

The advantages of composting biodegradable waste are the following: reducing waste, recycling nutrients in soil as fertilizers, reduction of pollutants from the surrounding air, prevent climate change, soil water protection and preventing soil erosions [7-17].

Some examples of analytical techniques and digestion methods for heavy metals determination from biodegradable waste are presented in Table 1.

Table 1. Procedures used for heavy metals determination from waste - reported data

\begin{tabular}{|c|c|c|c|c|}
\hline Sample waste & $\begin{array}{c}\text { Analytical } \\
\text { techniques/ } \\
\text { Metals }\end{array}$ & $\begin{array}{l}\text { Method of digestion/ } \\
\text { Reagents }\end{array}$ & Remarks & Ref. \\
\hline $\begin{array}{l}\text { Food wastes: including } \\
\text { brewer's spent grain, } \\
\text { apple pomace, } \\
\text { strawberry pomace, } \\
\text { carrot pomace, orange } \\
\text { and grapefruit peel, } \\
\text { beetroot and potato } \\
\text { peel, potato pulp, } \\
\text { rapeseed cake, walnut } \\
\text { and, hazelnut shells }\end{array}$ & $\begin{array}{l}\mathrm{AAS} / \mathrm{Pb} \\
\mathrm{Cd}, \mathrm{Cu} \\
\mathrm{Zn}, \mathrm{Cr}, \mathrm{Ni} \\
\mathrm{Na}, \mathrm{K}, \mathrm{Mg}\end{array}$ & $\begin{array}{l}\text { Microwave - closed system } \\
1 \mathrm{~g} \text { sample } \\
7 \mathrm{~mL} \mathrm{HNO}_{3}(65 \%)+ \\
1 \mathrm{~mL} \mathrm{H}_{2} \mathrm{O}_{2}(30 \%)\end{array}$ & $\begin{array}{l}\text { Certified reference material } \\
\text { (BCR-482, IRMM) was used to } \\
\text { validate the analytical } \\
\text { measurements. } \\
\text { The closed microwave digestion } \\
\text { method is adequate and accurate } \\
\text { for determining } \mathrm{Pb}, \mathrm{Cd}, \mathrm{Cu}, \mathrm{Zn} \text {, } \\
\mathrm{Cr}, \mathrm{Ni}, \mathrm{Na}, \mathrm{K}, \mathrm{Mg} \text { in food waste. }\end{array}$ & [6] \\
\hline $\begin{array}{lr}\text { Biomass } & \text { waste } \\
\text { from } & \text { agriculture, } \\
\text { forestry, and } & \text { related } \\
\text { industries } & \text { (waste } \\
\text { horticultural and wine) }\end{array}$ & $\begin{array}{l}\text { ICP-MS/ } \\
\text { AAS/ } \\
\mathrm{Al}, \mathrm{Mg}, \\
\mathrm{Ca}, \mathrm{K}, \mathrm{Na}, \\
\mathrm{Fe}\end{array}$ & $\begin{array}{l}\text { Microwave - closed system } \\
0.25 \mathrm{~g}-1 \mathrm{~g} \text { sample } \\
8 \mathrm{~mL} \mathrm{HNO}_{3}+2 \mathrm{~mL} \mathrm{H}_{2} \mathrm{O}_{2}\end{array}$ & $\begin{array}{l}\text { The concentration obtained for } \\
\mathrm{Al}, \mathrm{Mg}, \mathrm{K}, \mathrm{Ca}, \mathrm{Na} \text { and } \mathrm{Fe} \text { by } \\
\text { microwave digestion in a closed } \\
\text { system analyzed using the ICP- } \\
\text { MS technique were better than the } \\
\text { AAS technique. }\end{array}$ & [7] \\
\hline $\begin{array}{l}\text { Biomass } \\
\text { from } \\
\text { forestry agriculture, } \\
\text { industries }\end{array}$ & $\begin{array}{l}\text { ICP-MS/ } \\
\text { As, Cd, Pb }\end{array}$ & $\begin{array}{l}\text { Microwave - closed system } \\
0.5 \mathrm{~g} \text { ash }+10 \mathrm{~mL} \mathrm{HNO}_{3}\end{array}$ & $\begin{array}{l}\text { How the ash sample is prepared } \\
\text { from the biomass is therefore } \\
\text { crucial for obtaining reliable and } \\
\text { reproducible results. }\end{array}$ & [8] \\
\hline Sewage sludge & $\begin{array}{l}\text { AAS/ Cd, } \\
\mathrm{Cu}, \mathrm{Cr}, \mathrm{Pb}, \\
\mathrm{Ni} \text {, and } \mathrm{Zn}\end{array}$ & $\begin{array}{l}\text { a) Microwave - closed } \\
\text { system } \\
0.5 \mathrm{~g} \text { dried sample }\left(105^{\circ} \mathrm{C}\right) \\
+6 \mathrm{~mL} \mathrm{HNO}_{3}+2 \mathrm{~mL} \mathrm{HCl} \\
\text { b) Microwave }- \text { closed } \\
\text { system } \\
0.5 \mathrm{~g} \text { roasted sample }\left(600^{\circ} \mathrm{C}\right) \\
+6 \mathrm{~mL} \mathrm{HNO}_{3}+2 \mathrm{~mL} \mathrm{HCl} \\
\text { c) Wet acid digestion open } \\
\text { system } \\
1 \mathrm{~g} \mathrm{dried} \mathrm{sample}+ \\
12 \mathrm{~mL} \mathrm{HNO}_{3}+4 \mathrm{~mL} \mathrm{HCl}\end{array}$ & $\begin{array}{l}\text { Generally, method (b) was the } \\
\text { most effective. Methods (b) and } \\
\text { (c) yield complete decomposition } \\
\text { of the matrix. As a result, the } \\
\text { precision of measurement } \\
\text { substantially increases. } \\
\text { Microwave acid digestion in a } \\
\text { closed system allows } \\
\text { decomposing samples more } \\
\text { quickly than with conventional } \\
\text { mineralization. }\end{array}$ & [9] \\
\hline
\end{tabular}

The study aimed to develop and implement some characterization methods of biodegradable waste relevant to the composting process. 


\section{MATERIALS AND METHODS}

\section{Equipment}

Millipore Milli-Q Ultrapure Water System

Microwave Digestion System Ethos Up Milestone

ICP-MS type 7900 Agilent with Mass Hunter 4.4 software

AAS Perkin Elmer PinAAcle 900T

UV-VIS type 205 Specord Analytic Jena

\section{Reagents and calibration}

Calibration curves for $\mathrm{As}, \mathrm{Cd}, \mathrm{Cr}, \mathrm{Ni}, \mathrm{Cu}, \mathrm{Zn}, \mathrm{Pb}, \mathrm{K}$ were performed using a Multielement CRM $(100 \mathrm{mg} / \mathrm{L})$, traceable to NIST, containing 21 elements. Quality control of the analytical results was performed with a Multielement standard $(100 \mathrm{mg} / \mathrm{L})$ containing 23 elements, from Sigma Aldrich.

The sodium salicylate, sodium citrate dihydrate, sodium nitroprusside, sodium dichloro isocyanurate, sodium hydroxide, $\mathrm{HCl}$ and, $\mathrm{H}_{2} \mathrm{SO}_{4}$ used for the UV-VIS spectrophotometric method were purchased from Sigma Aldrich. To achieve the $\mathrm{NH}_{4}-\mathrm{N}$ calibration curve, was used ammonium chloride of $1000 \mathrm{mg} / \mathrm{L}$ (Sigma Aldrich quality). All the reagents used in the experiments were of quality grade.

For in-house validation experiments were used three different certified reference materials (CRMs) traceable to NIST, with ammonium nitrogen, total phosphorous, and metals content: sewage sludge (LRAC 4000), tomato leaves (1573a), and apple leaves (1515). In order to assess and develop the method, four types of waste were chosen: waste based on dehydrated sludge (P1); waste from parks (leaves and branches) (P2); market waste (mixture of vegetable and fruit scraps) (P3); cardboard waste (P4).

\section{The methods and sample preparation}

This complex study aimed at characterizing specific waste fractions in terms of metal content, total phosphorus, and ammonium nitrogen and the implementation at the laboratory level of the tested analytical methods. The samples preparation consisted in samples drying at $105^{\circ} \mathrm{C}$ and grinding at $40 \mathrm{~mm}$. Four digestion methods were applied to determine the total metals and phosphorus content (Table 2). For ammonium nitrogen content determination were applied three extraction method: in water, in $\mathrm{CaCl}_{2}$ and in $\mathrm{KCl}$.

The minor elements (As, $\mathrm{Cd}, \mathrm{Cr}, \mathrm{Ni}, \mathrm{Cu}, \mathrm{Zn}, \mathrm{Pb}$ ) from the waste fractions were determined using the ICP-MS technique in the concentration range $10 \div 50 \mu \mathrm{g} / \mathrm{L}$. The total phosphorus content was determined using the ICP-MS technique in the range of $100 \div 500 \mu \mathrm{g} / \mathrm{L}$. Total potassium was determined using the AAS technique in the range of concentrations $1 \div 5 \mathrm{mg} / \mathrm{L}$. The matrix effectremoving agent for the AAS technique was $1 \% \mathrm{LaCl}_{3}$. Ammonium nitrogen $\left(\mathrm{NH}_{4}-\mathrm{N}\right)$ was determined using UV-VIS technique in the range of concentrations $5 \div 40 \mu \mathrm{g} / \mathrm{L} \mathrm{N}$. The waste fractions were dried at $105^{\circ} \mathrm{C}$ and crushed under $40 \mathrm{~mm}$. The same sample preparation methods were applied for CRMs.

\section{Digestion step}

After the drying stage at $105^{\circ} \mathrm{C}$ and calcination at $550^{\circ} \mathrm{C}$, the samples were further mineralized according to Table 2 . The methods were adapted on the literature data presented in the introduction and according to the specific standards for bio-waste and sludge. 
Table 2. Digestion methods

\begin{tabular}{|c|c|c|c|c|c|c|}
\hline Waste fraction & Sample weight, g & Method & Steps & Power, W & Temp., ${ }^{\circ} \mathrm{C}$ & Time, minutes \\
\hline \multirow{3}{*}{$\begin{array}{l}\text { P1- Waste based on } \\
\text { dehydrated sludge }\end{array}$} & \multirow{3}{*}{$0.25-0.50$} & I Method & 1 & 1600 & \multirow{2}{*}{$160 * / 100 * *$} & 30 \\
\hline & & 7.5mL HCl + & 2 & 1600 & & 35 \\
\hline & & $2.5 \mathrm{~mL} \mathrm{HNO}_{3}$ & Cooling & - & - & 30 \\
\hline \multirow{3}{*}{$\begin{array}{l}\text { P2- Parks waste } \\
\text { (leaf-branches) }\end{array}$} & \multirow{3}{*}{$0.50-1$} & II Method & 1 & 1400 & \multirow{2}{*}{$120 * / 100 * *$} & 20 \\
\hline & & $9 \mathrm{~mL} \mathrm{HNO}_{3}+$ & 2 & 1400 & & 25 \\
\hline & & $1 \mathrm{~mL} \mathrm{H} \mathrm{O}_{2}$ & Cooling & - & - & 30 \\
\hline \multirow{3}{*}{ P3 - Market waste } & \multirow{3}{*}{$0.50-1$} & III Method & 1 & 1500 & \multirow{2}{*}{$140 * / 100 * *$} & 25 \\
\hline & & $8 \mathrm{~mL} \mathrm{HNO}_{3}+$ & 2 & 1500 & & 30 \\
\hline & & $2 \mathrm{~mL} \mathrm{H}_{2} \mathrm{O}_{2}$ & Cooling & - & - & 30 \\
\hline \multirow{3}{*}{$\begin{array}{l}\text { P4- Cardboard } \\
\text { waste }\end{array}$} & \multirow{3}{*}{$0.50-1$} & IV Method & 1 & 1200 & \multirow{2}{*}{$110 * / 100 * *$} & 15 \\
\hline & & & 2 & 1200 & & 25 \\
\hline & & & Cooling & - & - & 30 \\
\hline
\end{tabular}

* The temperature inside the vessels controlled by a temperature sensor in the reaction vessel 1;

** The temperature on the outside of the vessels controlled by IR sensor.

\section{Analyses}

The metals As, Cd, K, and total phosphorus were determined from the dried solid sample [18].

Moisture content: P1 (82.88\%); P2 (98.13); P3 (97.56) and P4 (97.12\%).

The other metals $(\mathrm{Pb}, \mathrm{Cr}, \mathrm{Cu}, \mathrm{Ni}, \mathrm{Zn}$ ) were determined from the sample residue (ash) obtained by samples calcination at $550^{\circ} \mathrm{C}$ [24]. Residue (ash) content: P1 (50.89\%); P2 (12.82); P3 (19.19) and P4 (3.26\%).

\section{In-house validation method for the determination of $\mathrm{NH}_{4} \mathrm{~N}$}

Three extraction methods were used to determine ammonium nitrogen content $\left(\mathrm{NH}_{4}-\mathrm{N}\right)$, as can be seen in Figure 1. The optimal method for the determination of ammonium nitrogen in the waste samples was validated.in-house. The repeatability, intermediary precision, quantification limit (LOQ), detection limit (LOD), recovery and expanded uncertainty were evaluated.

A five-point calibration curve was drawn for the ammonium nitrogen content from a $1 \mathrm{mg} / \mathrm{L}$ ammonium nitrogen standard solution: $5 \mu \mathrm{g}, 10 \mu \mathrm{g}, 20 \mu \mathrm{g}, 30 \mu \mathrm{g}, 40 \mu \mathrm{g}$, using UV-VIS technique at $655 \mathrm{~nm}$ wavelength. The correlation factor $\left(\mathrm{R}^{2}\right)$ was 0.9998 . To verify the ammonium nitrogen method a certified reference material for sewage sludge was used.

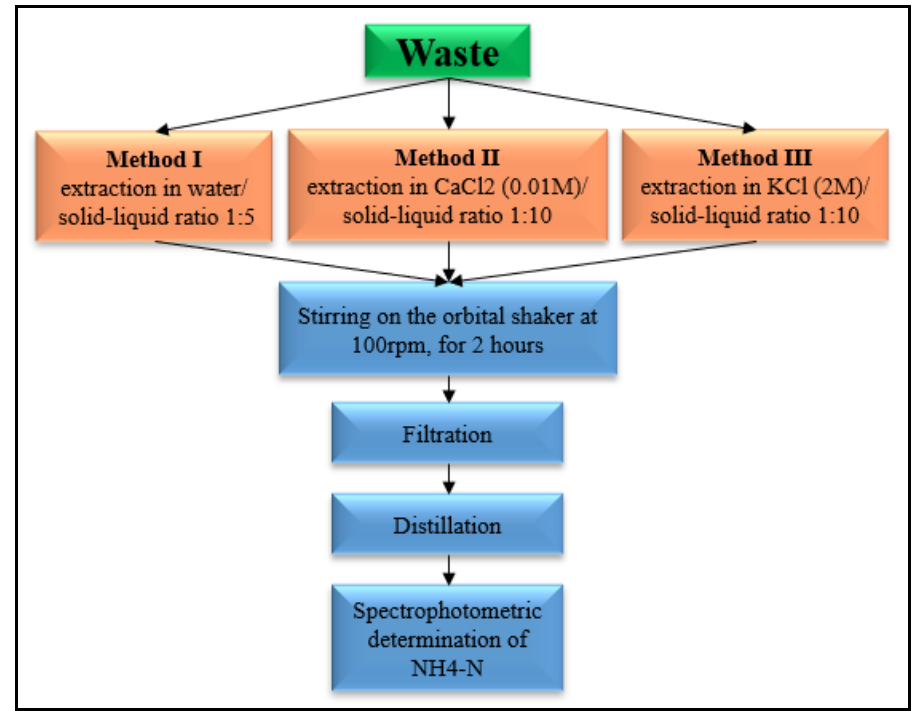

Fig. 1. Scheme for determining the ammonium nitrogen $\left(\mathrm{NH}_{4}-\mathrm{N}\right)$ content in waste

The tested performance parameters of the study are presented in Table 3. 
Table 3. The in-house validation experiments for $\mathrm{NH}_{4}-\mathrm{N}$

\begin{tabular}{l|l}
\hline \multicolumn{1}{c|}{ Parameters } & \multicolumn{1}{c}{ Experiments } \\
\hline LOD and LOQ & 10 independent fortified sample solutions with $2 \mu \mathrm{g} \mathrm{NH} 4-\mathrm{N}$ \\
Repeatability & 10 independent fortified sample solutions with $15 \mu \mathrm{g} \mathrm{NH}_{4}-\mathrm{N}$ \\
Intermediate precision & 12 independent fortified sample solutions with $15 \mu \mathrm{g} \mathrm{NH}_{4}-\mathrm{N}$ \\
Recovery & 5 independent fortified sample solutions with $25 \mu \mathrm{g} \mathrm{NH}-\mathrm{N}$ \\
\hline
\end{tabular}

The extraction methods for ammonium nitrogen were performed according to the standardized methods [19-21]. With one minor exception, the samples were stirred on Shaker $2 \mathrm{~h}$ instead of one hour and at a stirring speed of 100rpm.

The determination of ammonium nitrogen was performed by using a UV-VIS method at $655 \mathrm{~nm}$ [22-24]. All samples were filtered, distilled, and the appropriate method for determining ammonium nitrogen was applied.

\section{RESULTS AND DISCUSSION}

In-house validation for $\mathrm{NH}_{4}-\mathrm{N}$

Table 4 presents the values of the performance parameters obtained for in-house validation of $\mathrm{NH}_{4-}$ $\mathrm{N}$ method using the UV-VIS technique and digestion method III. Validations for total phosphorus and metals content were reported in previous studies $[13,14]$.

Table 4. Performance parameters for $\mathrm{NH}_{4}-\mathrm{N}$, after application of $2 \mathrm{M} \mathrm{KCl}$ extraction

\begin{tabular}{c|cccccc}
\hline Sample & LOD, $\mathrm{mg} / \mathrm{kg}$ & $\mathrm{LOQ}, \mathrm{mg} / \mathrm{kg}$ & RSDr*, $\%$ & RSD $_{\mathrm{R}}^{* *}, \%$ & Recovery, \% & Uex $^{* * *}, \%$ \\
\hline P1 & 0.012 & 0.039 & 2.25 & 2.61 & 98.4 & 11.3 \\
P2 & 0.020 & 0.066 & 1.94 & 2.36 & 97.6 & 10.5 \\
P3 & 0.031 & 0.100 & 2.50 & 2.79 & 91.2 & 12.6 \\
P4 & 0.023 & 0.080 & 2.43 & 2.64 & 92.8 & 11.5 \\
\hline
\end{tabular}

*Repeatability test; $* *$ Intermediate precision; $* * *$ Expanded uncertainty

The method for $\mathrm{NH}_{4}-\mathrm{N}$ analysis from the waste is precise, accurate, presenting small detection and quantification limits (Table 4). The recovery yield of $\mathrm{NH}_{4}-\mathrm{N}$ is over $98 \%$ for dehydrated sludge. For the rest of the samples, the recovery yield is P2 (97.6\%), P3 (91.2\%), and P4 (92.8\%).

The lowest limits of detection and quantification were recorded for sample P1 (dehydrated sludge) and the highest for sample P3 (market waste). The results obtained were influenced by each sample composition, the extraction time, and the stirring speed. For the calculation of the expanded uncertainty the following parameters were taken into account: standard deviation of repeatability, the standard deviation of reproducibility, purity of reagents, the uncertainty of laboratory glassware, CRM uncertainty for sludge, and CRMs uncertainty for biomass, the measuring range $(5 \div 40 \mu \mathrm{g}$ $\mathrm{NH}_{4}-\mathrm{N}$ ) and uncertainty of UV-VIS equipment. The lowest uncertainty value was obtained for the P2 (10.5\%) sample composed of park waste, and the highest measurement uncertainty was obtained for the P3 (12.6\%) sample composed of market waste. The validation method for cellulosic waste (P2, P3 and P4) was performed on real waste samples due to the lack of a significant CRM for the ammonium nitrogen content.

\section{Determination of $\mathrm{NH}_{4}-\mathrm{N}$ using three extraction methods}

Three different extraction methods were applied to a reference material with certified values for ammonium nitrogen (sewage sludge LRAC 4000). The results obtained are presented in Table 5. The certified reference material (CRM) demonstrated the accuracy of the method and the reproducibility of the results for extraction method III. 
Table 5. Ammonium nitrogen $\left(\mathrm{NH}_{4}-\mathrm{N}\right)$ content in LRAC $4000 \mathrm{CRM}, \mathrm{mg} / \mathrm{kg}$ d.m.

\begin{tabular}{c|cccc}
\hline Parameter & Method & Certificate value & Obtained value & RecoveryYield (\%) \\
\hline \multirow{3}{*}{$\mathrm{NH}_{4}-\mathrm{N}$} & Method I & $4700 \pm 457$ & $3956 \pm 633$ & 84.2 \\
& Method II & $4700 \pm 457$ & $4216 \pm 594$ & 89.7 \\
& Method III & $\mathbf{4 7 0 0 \pm 4 5 7}$ & $\mathbf{4 6 1 7} \pm \mathbf{4 6 2}$ & $\mathbf{9 8 . 2}$ \\
\hline
\end{tabular}

\pm expanded uncertainty

Based on the results obtained, it can be stated that the $\mathrm{KCl}$ extraction method is better compared to the other two methods (extraction in water and $\mathrm{CaCl} 2$ ). The result obtained for ammonium nitrogen falls within the measurement uncertainty of the method and certificated value. The value of ammonium nitrogen recovery by the $\mathrm{KCl}$ extraction method $(98.2 \%)$ was higher compared to the other two extraction methods (Table 5). In addition, the ammonium nitrogen content of the sludge sample by extraction method III is higher than the other methods (Table 5).

Table 6. Ammonium nitrogen $\left(\mathrm{NH}_{4}-\mathrm{N}\right)$ in samples, $\mathrm{mg} / \mathrm{kg}$ d.m.

\begin{tabular}{c|ccc}
\hline Sample results & Method I & Method II & Method III \\
\hline P1 & $30.64 \pm 4.90$ & $23.81 \pm 3.33$ & $69.87 \pm 6.99$ \\
P2 & $1.556 \pm 0.25$ & $1.209 \pm 0.17$ & $3.439 \pm 0.34$ \\
P3 & $19.206 \pm 3.07$ & $14.923 \pm 2.09$ & $38.03 \pm 3.80$ \\
P4 & $0.415 \pm 0.066$ & $0.322 \pm 0.045$ & $0.755 \pm 0.076$ \\
\hline
\end{tabular}

\pm expanded uncertainty

As can be seen from Tables 5 and 6, the highest ammonium nitrogen content is found in the P1 (dehydrated sludge) sample, followed by the P3 (market waste) sample. For all the samples, the highest results were obtained using extraction method III (extraction in $\mathrm{KCl}$ ) and, the lowest results were obtained using method II (extraction in $\mathrm{CaCl}_{2}$ ). The extraction methods for ammonium nitrogen depend on the waste composition, sample $\mathrm{pH}$, drying temperature, and sample extraction procedures.

\section{Determination of total phosphorous content}

To determine the total phosphorous, four digestion methods were used for organic matter decomposition. Digestion methods are described in Table 2. Total phosphorus validation procedures have been extensively presented in another article [14].

The analysis method was verified with three certified reference materials (CRM) with known total phosphorus content: apple leaves, tomato leaves and sewage sludge.

Table 7. Total phosphorus from sewage sludge LRAC 4000 CRM, mg/kg d.m.

\begin{tabular}{c|cccc}
\hline Parameter & Method & Certificate value & Obtained value & Recovery Yield (\%) \\
\hline \multirow{3}{*}{ Total phosphorous } & Method I & $2.11 \pm 0.260$ & $2.00 \pm 0.300$ & 94.79 \\
& Method II & $\mathbf{2 . 1 1} \pm \mathbf{0 . 2 6 0}$ & $\mathbf{2 . 0 3 \pm \mathbf { 0 . 2 7 4 }}$ & $\mathbf{9 7 . 1 6}$ \\
& Method III & $2.11 \pm 0.260$ & $1.91 \pm 0.287$ & 90.52 \\
& Method IV & $2.11 \pm 0.260$ & $1.80 \pm 0.270$ & 85.30 \\
\hline
\end{tabular}

\pm expanded uncertainty

Table 8. Total phosphorus in tomato leaves (1573a) and apple leaves (1515) CRM, mg/kg d.m.

\begin{tabular}{c|cccccc}
\hline \multirow{2}{*}{ Method } & \multicolumn{4}{|c}{$\mathbf{1 5 7 3 a}$} & \multicolumn{1}{c}{$\mathbf{1 5 1 5}$} \\
\cline { 2 - 7 } & $\begin{array}{c}\text { Certificate } \\
\text { value }\end{array}$ & $\begin{array}{c}\text { Obtained } \\
\text { value }\end{array}$ & $\begin{array}{c}\text { Recovery, } \\
\text { \% }\end{array}$ & $\begin{array}{c}\text { Certificate } \\
\text { value }\end{array}$ & $\begin{array}{c}\text { Obtained } \\
\text { value }\end{array}$ & $\begin{array}{c}\text { Recovery, } \\
\mathbf{\%}\end{array}$ \\
\hline Method I & $2161 \pm 28$ & $2135 \pm 203$ & 98.80 & $1593 \pm 68$ & $1532 \pm 130$ & 96.17 \\
Method II & $\mathbf{2 1 6 1} \pm \mathbf{2 8}$ & $\mathbf{2 1 3 8} \pm \mathbf{2 0 3}$ & $\mathbf{9 8 . 9 4}$ & $\mathbf{1 5 9 3} \pm \mathbf{6 8}$ & $\mathbf{1 5 4 0 \pm 1 3 1}$ & $\mathbf{9 6 . 6 7}$ \\
Method III & $2161 \pm 28$ & $2134 \pm 186$ & 98.75 & $1593 \pm 68$ & $1529 \pm 133$ & 95.98 \\
Method IV & $2161 \pm 28$ & $2133 \pm 190$ & 98.70 & $1593 \pm 68$ & $1525 \pm 136$ & 95.73 \\
\hline
\end{tabular}

\pm expanded uncertainty 
The digestion method II in the presence of nitric acid and hydrogen peroxide presents highest results for the determination of total phosphorus content for all samples. In addition, applying the digestion method II, the highest recovery yields (higher than 96\%) of the total phosphorus were obtained from the three certified reference materials, both for the sludge matrix and for the biomass matrix (tables 7 and 8).

Table 9. Total phosphorus content in samples, $\mathrm{mg} / \mathrm{kg} \mathrm{d} . \mathrm{m}$.

\begin{tabular}{c|cccc}
\hline Sample results & Method I & Method II & Method III & Method IV \\
\hline P1 & $124 \pm 11.78$ & $\mathbf{1 3 5} \pm \mathbf{1 0 . 1 3}$ & $121 \pm 7.87$ & $116 \pm 8.47$ \\
P2 & $32 \pm 3.04$ & $\mathbf{3 8} \pm \mathbf{2 . 8 5}$ & $31 \pm 2.02$ & $25 \pm 1.83$ \\
P3 & $89 \pm 8.46$ & $\mathbf{9 6} \pm \mathbf{7 . 2 0}$ & $81 \pm 5.27$ & $72 \pm 5.20$ \\
P4 & $0.12 \pm 0.011$ & $\mathbf{0 . 1 8} \pm \mathbf{0 . 0 1 4}$ & $0.09 \pm 0.006$ & $0.05 \pm 0.004$ \\
\hline
\end{tabular}

\pm expanded uncertainty

Not only for CRMs higher results were obtained but also for all samples prepared by digestion method II, as it can be seen in Table 9.

Applying methods I, III and IV for the digestion of samples in a closed microwave system, lower total phosphorus recovery yields were obtained for each waste fraction. The total phosphorus content was influenced by the following parameters: the composition of the waste, the mixture of acids for mineralization, as well as the temperature and microwave power of the digestion stage. These parameters contributed to the oxidation of all forms of phosphorus (polyphosphates and organic phosphorus) from waste samples to total phosphorus.

The dehydrated sludge sample contains humic acids, while vegetable samples and cardboard waste contain cellulose, hemicellulose and many colored substances such as tannins, polyphenols and flavones that must be eliminated in digesting step. These factors influenced the results for the total phosphorus content. Depending on the sample matrix for which it is desired to determine the total phosphorus content, the digestion method is subsequently selected, taking into account the composition of the sample.

\section{Determination of total metals content}

The most important aspects of the study were the preparation and the digestion methods of all waste fractions. At the end of the study, the best digestion and extraction methods were selected for each of the waste fraction. The metals were analyzed both on the dried samples (As, $\mathrm{Cd}, \mathrm{K}$ ) and from the residue (ash) $(\mathrm{Cr}, \mathrm{Ni}, \mathrm{Cu}, \mathrm{Zn}, \mathrm{Pb})$ obtained by calcination at $550^{\circ} \mathrm{C}$.

In order to ensure the validity of the results obtained for sewage sludge (P1), park waste (P2), market waste (P3) and cardboard waste (P4), three certified reference materials were used (sewage sludge LRAAC4000, leaves of tomatoes 1573a and apple leaves 1515). The CRM for tomato leaves does not contain lead, and the CRM for apple leaves does not contain chromium and arsenic. The CRMs results obtained by the four digestion methods are presented in Tables 10 and 11 .

Table 10. Total metals content from CRMs, $\mathrm{mg} / \mathrm{kg}$ d.m.

\begin{tabular}{c|cccccc}
\hline Metal & \multicolumn{3}{|c}{ LRAAC 4000 (Method I) } & \multicolumn{3}{c}{1573 a (Method II) } \\
& Certificate value & Obtained value & $\begin{array}{c}\text { Recovery, } \\
\%\end{array}$ & Certificate value & Obtained value & $\begin{array}{c}\text { Recovery, } \\
\%\end{array}$ \\
\hline $\mathrm{As}$ & $256 \pm 9$ & $248.5 \pm 29$ & 97.07 & $0.1126 \pm 0.0024$ & $0.1102 \pm 0.0121$ & 97.87 \\
$\mathrm{Cd}$ & $122.7 \pm 0.26$ & $122.5 \pm 12$ & 99.84 & $1.517 \pm 0.027$ & $1.512 \pm 0.151$ & 99.67 \\
$\mathrm{Cr}$ & $353 \pm 12$ & $345 \pm 39$ & 97.73 & $1.988 \pm 0.034$ & $1.986 \pm 0.238$ & 99.91 \\
$\mathrm{Ni}$ & $127 \pm 4$ & $125 \pm 15$ & 98.43 & $1.582 \pm 0.041$ & $1.575 \pm 0.189$ & 99.56 \\
$\mathrm{Cu}$ & $736 \pm 33$ & $729 \pm 95$ & 99.05 & $4.70 \pm 0.14$ & $4.64 \pm 0.46$ & 98.72 \\
$\mathrm{Zn}$ & $1080 \pm 20$ & $1076 \pm 140$ & 99.63 & $30.94 \pm 0.55$ & $29.97 \pm 3.30$ & 96.86 \\
$\mathrm{~Pb}$ & $119 \pm 5$ & $117 \pm 13$ & 98.49 & - & - & - \\
$\mathrm{K}$ & $4918 \pm 975$ & $4875 \pm 585$ & 99.13 & $26760 \pm 480$ & $26751 \pm 2408$ & 99.97 \\
\hline
\end{tabular}


Based on the implementation of the method of metal content analysis we can say that the results obtained are reproducible (tables 10 and 11). The highest recovery yield was obtained for cadmium (99.84\%) while the lowest one for arsenic (97.07\%). The highest concentrations of metals were recorded for potassium from dehydrated sludge, while the lowest concentrations were recorded for cadmium. The uncertainty of the working method was applied to each result obtained.

Table 11. Total metals content from 1515 CRM, mg/kg d.m.

\begin{tabular}{c|ccccc}
\hline Metal & Certificate & \multicolumn{2}{c}{ Method III } & \multicolumn{2}{c}{ Method IV } \\
& value & Obtained value & Recovery, \% & Obtained value & Recovery, \% \\
\hline $\mathrm{Cd}$ & $0.0132 \pm 0.0015$ & $0.0129 \pm 0.0013$ & 97.73 & $0.0125 \pm 0.00125$ & 94.70 \\
$\mathrm{Ni}$ & $0.936 \pm 0.094$ & $0.929 \pm 0.1115$ & 99.25 & $0.918 \pm 0.1102$ & 98.08 \\
$\mathrm{Cu}$ & $5.69 \pm 0.13$ & $5.63 \pm 0.563$ & 98.95 & $5.60 \pm 0.560$ & 98.42 \\
$\mathrm{Zn}$ & $12.54 \pm 0.43$ & $12.37 \pm 1.36$ & 98.64 & $12.37 \pm 1.36$ & 98.64 \\
$\mathrm{~Pb}$ & $0.470 \pm 0.024$ & $0.462 \pm 0.0462$ & 98.30 & $0.462 \pm 0.0462$ & 98.30 \\
$\mathrm{~K}$ & $16080 \pm 210$ & $16069 \pm 1446$ & 99.93 & $16069 \pm 1446$ & 99.93 \\
\hline
\end{tabular}

\pm expanded uncertainty

For market waste and cardboard waste, the working method was verified with a certified reference material based on apple leaves (1515) by two methods of digestion corresponding to the studied matrices. By method III of digestion in the presence of nitric acid and hydrogen peroxide, a higher metal content was obtained for the CRM in apple leaves compared to method IV of digestion in the presence of nitric acid. Zinc, lead and potassium were not influenced by the applied digestion method, only cadmium, nickel and copper showed higher results by digestion method III (table 11). The metal recovery were situated in the range $97.73 \%$ to $99.93 \%$ for method III and from $94.70 \%$ to 99.93 for digestion method IV (Table 11). Digestion temperature and microwave power also influenced the results obtained for the total metal content. The results obtained for the metal content of the three CRMs (sewage sludge, tomato leaves and apple leaves) fall within the measurement uncertainty of the analytical method.

The results obtained for the total metal content of all the studied samples are presented in Table 12 .

Table 12. Results obtained for total metals for all the samples, $\mathrm{mg} / \mathrm{kg}$ d.m.

\begin{tabular}{c|cccc}
\hline Metal & P1 (Method I) & P2 (Method II) & P3 (Method III) & P4 (Method IV) \\
\hline $\mathrm{As}$ & $42.2 \pm 5.06$ & $2.11 \pm 0.23$ & $3.40 \pm 0.374$ & $1.33 \pm 0.146$ \\
$\mathrm{Cd}$ & $1.08 \pm 0.108$ & $0.70 \pm 0.070$ & $0.74 \pm 0.074$ & $0.63 \pm 0.063$ \\
$\mathrm{Cr}$ & $32.66 \pm 4.25$ & $0.37 \pm 0.044$ & $15.71 \pm 18.9$ & $2.74 \pm 0.329$ \\
$\mathrm{Ni}$ & $8.30 \pm 0.83$ & $13.14 \pm 1.58$ & $13.14 \pm 1.58$ & $2.24 \pm 0.269$ \\
$\mathrm{Cu}$ & $23.81 \pm 3.10$ & $1.77 \pm 0.18$ & $11.08 \pm 1.11$ & $3.67 \pm 0.367$ \\
$\mathrm{Zn}$ & $163 \pm 21.19$ & $8.79 \pm 0.97$ & $42.91 \pm 4.72$ & $8.33 \pm 0.916$ \\
$\mathrm{~Pb}$ & $9.43 \pm 1.04$ & $0.25 \pm 0.025$ & $16.72 \pm 1.67$ & $6.93 \pm 0.693$ \\
$\mathrm{~K}$ & $1995 \pm 239$ & $507 \pm 46$ & $1871 \pm 168$ & $350 \pm 32$ \\
\hline
\end{tabular}

\pm expanded uncertainty

For each waste fraction, the optimal digestion method was applied to correctly determine the metal content. Initially, an attempt was made to apply each digestion method for the four waste fractions and subsequently the optimal digestion method was selected for each waste category. Table 12 show the optimal digestion methods for the four categories of waste, for which the highest metal concentrations and the most reproducible results were obtained.

The highest concentrations of metals were obtained for dehydrated sludge, followed by market waste, park waste and cardboard waste as it can be seen in Table 12. Dehydrated sludge (P1) recorded high values for $\mathrm{As}, \mathrm{Cd}, \mathrm{Cr}$. $\mathrm{Ni}, \mathrm{Cu}, \mathrm{Zn}, \mathrm{K}$, with an exception for lead which is present in small quantity $(9.43 \mathrm{mg} / \mathrm{kg} \mathrm{d.m})$ in comparison with the lead from the market waste $(16.72 \mathrm{mg} / \mathrm{kg}$ d.m). The cardboard waste presents a small exception for the lead concentrations which has a high content $(6.93 \mathrm{mg} / \mathrm{kg} \mathrm{d.m})$ in comparison with the lead from the park waste $(0.25 \mathrm{mg} / \mathrm{kg} \mathrm{d} . \mathrm{m})$. 


\section{CONCLUSIONS}

The study consisted in the development and implementation of methods for compositional characterization of biodegradable waste with relevance for the composting process. The minor and major elements in the composition of four waste fractions were analyzed by several analytical techniques: ICP-MS, AAS and UV-VIS for the subsequent implementation at laboratory level. The parameters followed in this study were the following: sample preparation methods (drying and grinding), digestion and extraction methods and subsequently analytical techniques.

The method developed for ammonium nitrogen using UV-VIS technique has been validated internally. The highest recovery for ammonium nitrogen (98\%) were obtained using method III (extraction in $\mathrm{KCl}$ ), followed by method I (extraction in water) and method II (extraction in $\mathrm{CaCl}_{2}$ ). The results obtained for the ammonium nitrogen, total phosphorus and metals content were compared with certified reference materials (CRM) to verify the validity of the experimental results. For all investigated parameters, the results are accurate, precise and reproducible.

For the metals content, recovery yields of over $97 \%$ were obtained. The best results for the metals content and for the phosphorus content were obtained using the digestion method II in the presence of nitric acid and hydrogen peroxide at a $120^{\circ} \mathrm{C}$ digestion temperature. Microwave acid digestion in a closed system allows decomposing samples more quickly than that with conventional mineralization and is suitable for volatile metals, which are no longer lost during the digestion stage.

The methods tested and implemented in this study for different waste fractions will help to select the optimum "secondary raw materials" for the composting stage. It is known that waste has characteristics and chemical composition that can change during composting conditions, the methods developed and presented in this paper are a useful tool for characterizing the different waste fractions that enter in the composting stage as well as the final compost after the anaerobic stage of fermentation

\section{REFERENCES}

[1] BIODEGRADABLE WASTE, https://ec.europa.eu/environment/topics/waste-and-recycling/ biodegradable-waste_en, [15.09.2021].

[2] DIRECTIVE EU 2018/851 of the European Parliament and of the Council, https://www.legislation.gov.uk/eudr/2018/851/article/1/2020-01-31 [15.09.2021].

[3] LAW 181/2020 on the management of compostable non-hazardous waste, February 20, 2021, https://www.mabecoweb.net/uploads/2/3/9/9/23993238/2020.08.23_legea-181-2020-

a_compostului.pdf [20.12.2021].

[4] MATEI, E., RAPA, M., PREDESCU, A.M., TURCANU, A.A., VIDU, R., PREDESCU C., BOBIRICA, C., BOBIRICA, L., ORBECI, C., Materials, 14, no. 16, 2021, p. 1, https://doi.org/10.3390/ma14164581.

[5] GONZALEZ-SUAREZ A., PEREDA-REYES I., OLIVA-MERENCIO D., MONTALVOMARTINEZ S. J., Rev. Fac. de Ing, no.101, 2021, p. 55.

[6] BOZYM, M., FLORCZAK, I., ZDANOWSKA, P., WOJDALSKI, J., KLIMKIEWICZ, M., Renewable Energy, 77, no. 5, 2015, p. 467.

[7] TRAISTARU, G.A., SERBANESCU, A., BARBU, M., NICOLESCU, I., CRISTEA, N.I., STANESCU, B., COVALIU, I.C., Proceedings Book of $21^{\text {st }}$ of International Symposium "The Environment and the Industry", Bucharest, Romania, 20-21 September 2018, p. 347, http://doi.org/10.21698/simi.2018.fp41.

[8] KIM, L., CATRINA, G.A., COVALIU, C.I., PASCU, L.F., CRISTEA, I., SERBANESCU, A., CERNICA, G., Rev. Chim., 70, no. 12, 2019, p. 4584.

[9] TUREK, A., WIECZOREK K., WOLF, W.M., Sustainability, 11, no. 6, 2019, p. 1, https://doi.org/10.3390/su11061753. 
[10] LONG, Y.-Y., SHEN, D.-S., WANG, H.-T., LU, W.-J., ZHAO, Y., J. Hazard. Mater., 186, 2011, p.1082.

[11] KAWASAKI, A., ARAI, S., Soil Sci. Plant Nutr., 42, no. 2, 1996, p. 251, http://doi.org/10.1080/00380768.1996.10415095.

[12] BRUlEA, M., BOLDUANA, R., SEIDELTA, S., SCHLAGERMANNB, P., BOTTC, A., Environ. Technol., 34, no. 13-16, 2013, p. 2047.

[13] CATRINA, G.A., KIM, L., PASCU, L.F., SERBANESCU, A., CERNICA, G., CRISTEA, I., BARBU, M., Proceedings Book of $22^{\text {nd }}$ of International Symposium "The Environment and the Industry", Bucharest, Romania, 26-27 September 2019, p. 246, http://doi.org/10.21698/simi.2019.ab32. [14] CATRINA, G.A., KIM, L., SERBANESCU, A., CERNICA, G., CRISTEA, I., BARBU, M., NICOLESCU, I., VASILE, G.G., Rom. J. Ecol. Environ. Chem., 2020, 2, no. 2, p. 138, https://doi.org/10.21698/rjeec.2020.217.

[15] U.S. EPA. Municipal Solid Waste Generation, Recycling, and Disposal in the United States: Facts and Figures for 2010, United States Environmental Protection Agency, Washington, 2010.

[16] ALLISON, A.L., LORENCATTO, F., MICHIE, S., MIODOWNIK, M., Sustainability, 13, no. 3, 2021, p. 1, https://doi.org/10.3390/su13031463.

[17] OSRA, F.A., OZCAN, H.K., ALZAHRANI, J.S., ALSOUFI, M.S., Sustainability, 13, no. 3, 2021, p. 1, https://doi.org/10.3390/su13031462.

[18] SR EN 16171:2017. Sludge, treated biowaste and soil. Determination of elements using inductively coupled plasma mass spectrometry (ICP-MS).

[19] SR EN 14671:2008. Characterization of sludges. Pre-treatment for the determination of extractable ammonia using $2 \mathrm{~mol} / \mathrm{L}$ potassium chloride.

[20] ISO 14255:1988. Soil quality. Determination of nitrate nitrogen, ammonium nitrogen and total soluble nitrogen in air-dry soils using calcium chloride solution as extractant.

[21] SR EN 13652:2002. Soil improvers and growing media. Extraction of water-soluble nutrients.

[22] SR EN 16192:2012. Characterization of waste. Analysis of eluates.

[23] ISO 5664:1984. Water quality. Determination of ammonium content. Distillation and titration method.

[24] ISO 7150-1:1984. Water quality. Determination of ammonium, Part 1: Manual spectrometric method.

Citation: Catrina, G.A., Kim, L., Serbanescu, A., Cernica, G., Bumbac, C., Sburlis, M., Chemical characterization methods for biodegradable organic wastes with relevance for the composting process. Case study, Rom. J. Ecol. Environ. Chem., 2021, 3, no.2, pp. 152-161.

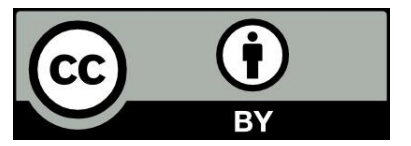

(C) 2021 by the authors. This article is an open access article distributed under the terms and conditions of the Creative Commons Attribution (CC BY) license (http://creativecommons.Org/licenses/by/4.0/). 